\title{
SMART TROLLEY PADA FITRINOPANE SWALAYAN DENGAN MENERAPKAN METODE BRUTE FORCE BERBASIS MOBILE
}

\author{
Yuni Puspita Sari ${ }^{1}$, Isnandar Agus ${ }^{2}$, Endang Puspita Sari ${ }^{3}$ \\ ${ }^{1}$ Fakultas Ilmu Komputer, Informatics \& Business Institute Darmajaya \\ Jl. Z.A. Pagar Alam No. 93, Bandar Lampung - Indonesia 35142 \\ Telp. (0721) 787214 Fax. (0721) 700261 \\ e-mail: yunipuspita@darmajaya.ac.id ${ }^{1}$, isnandaragus@darmajaya.ac.id ${ }^{2}$, \\ endangpuspitas41@gmail.com ${ }^{3}$
}

\begin{abstract}
The operating activities of a supermarket include all transactions. One of which is the payment of groceries. With a limited number of cashiers, it causes problems such as the buildup of queues at the cashier. In the consumer view, consumers often do not pay attention to the total price of the purchases taken. Thus, the budget does not match the accumulation of the items taken. This application was designed using the prototype development method and the brute force algorithm. The brute force algorithm looked for matches between the pattern and the text one by one from left to right. This algorithm was able to shift continuously every time a mismatch was found until the pattern was at the end of the text. The result of this study found that a mobile application made consumers finding out the accumulated prices of goods directly and easily by using a barcode scan on the goods. Moreover, it also eased to search for the desired goods by using the search feature based on product descriptions and product categories. Thus, consumers were able to control the spending budget according to the budget without worry at the checkout.
\end{abstract}

Keywords - Mobile, Scan Barcode, Prototype

\begin{abstract}
ABSTRAK
Aktivitas operasi suatu supermarket meliputi seluruh transaksi yang dimana salah satunya adalah pembayaran belanjaan. Dengan jumlah kasir yang terbatas, tentu saja menimbulkan permasalahan seperti penumpukan antrean dikasir. Pada sisi konsumen, seringkali konsumen tidak memperhatikan total harga dari belanjaan yang telah diambil. Sehingga, menimbulkan permaslahan ketidaksesuain budget dengan total akumulasi dari barang yang diambil. Aplikasi ini dirancang menggunakan metode pengembangan prototype serta algoritma brute force. Algoritma brute force berfungsi sebagai mencari kecocokan antara pola dan teks satu per satu dari kiri ke kanan. Algoritma bekerja dengan cara penggeseran pada saat tidak ditemukan ketidakcocokan, sampai pola berada diujung teks. Penelitian ini menghasilkan aplikasi mobile untuk memudahkan konsumen dalam mengetahui akumulasi harga barang secara langsung dengan menggunakan scan barcode pada barang dan mencari barang yang diinginkan dengan menggunakan fitur pencarian berdasarkan deskripsi produk dan kategori produk. Sehingga, konsumen dapat mengontrol anggaran belanja sesuai dengan budget yang dimiliki tanpa perlu khawatir pada saat transaksi dikasir.
\end{abstract}

Kata kunci : Mobile, Scan Barcode, Prototype 


\section{Pendahuluan}

Pada umumnya berbelanja dapat dilakukan di pasar baik itu pasar tradisional maupun pasar modern (supermarket). Pasar modern (supermarket) merupakan pasar yang dikelola dengan menggunakan manajemen secara modern, biasanya terdapat diperkotaan, dalam hal ini penyedia barang dan jasa dengan mutu dan pelayanan yang baik kepada konsumen dari segala kalangan merupakan faktor pendukung. Dari segi kualitas, pasar modern memiliki persediaan barang di gudang yang terukur. Dalam pasar modern, konsumen dan produsen tidak bertransaksi secara langsung. Konsumen melihat dan memilih barang yang akan dibeli serta melihat label harga yang tercantum, pelayanannya dilakukan secara mandiri (swalayan) atau dilayani oleh pramuniaga.

Fitrinofane Swalayan adalah salah satu badan usaha yang bergerak dibidang penjualan. Berdasarkan data dan observasi pada Fitrinofane Swalayan dalam 1 jam dapat melakukan transaksi sebanyak \pm 50 konsumen di hari kerja, dan \pm 100 orang di akhir pekan. Peningkatan transaksi sebanyak $25 \%$ terjadi di tanggal 25 sampai dengan 30 akhir bulan dan diawal bulan pada tanggal 1 sampai dengan 5. Dengan jumlah meja kasir sebanyak 2 buah, tentu saja hal ini menimbulkan beberapa permasalahan seperti penumpukan antrean dikasir yang memakan waktu. Pada sisi konsumen, permasalahan yang sering muncul adalah ketika berbelanja dalam jumlah yang banyak, terkadang konsumen tidak memperhatikan berapa jumlah total akumulasi transaksi belanjaan yang telah diambil [1]. Permasalahn selama ini yang terjadi adalah ketidaksesuaian anggaran konsumen dengan total harga yang harus dibayarkan. Permasalahan lain yang muncul adalah ketika konsumen harus mengantri untuk menghitung total akumulasi harga dikasir atau tempat pembayaran. Pada proses transaksi tersebut menghabiskan dan menyita waktu yang cukup lama jika terdapat banyak konsumen yang mengantre. Hal ini didukung berdasarkan dari hasil wawancara dari beberapa konsumen. Sebanyak 8 dari 10 konsumen mengalami permasalahan yang sama. Pada akhirnya, konsumen yang mengantri mengganggap bahwa menunggu antrean adalah hal yang paling membosankan karena harus berdiri untuk waktu yang cukup lama. 


\section{Metode Penelitian}

\subsection{Metode Pengumpulan Data}

Metode pengumpulan data merupakan satu cara memperoleh data data yang diperlukan dalam penelitian. Dalam penelitian ini tahap mengumpulkan data dan teknik yang digunakan antara lain sebagai berikut:

\section{a. Wawancara}

Wawancara merupakan salah satu teknik yang dapat digunakan untuk mengumpulkan data penelitian. Dalam tahap ini peneliti melakukan wawancara kepada pihak yang berwenang di bagian Fitrinop Swalayan, proses interaksi yang dilakukan adalah dengan melakukan interview sebagai sumber informasi atau orang yang di wawancarai melalui komunikasi langsung.

\section{b. Observasi}

Observasi merupakan teknik dalam pengumpulan data yang sangat lazim Observasi yang dilakukan dalam tahap peneltian ini dengan melihat langsung di lapangan dari aktifitas transaksi pada tempat penelitian untuk mendapatkan data sebagi acuan dalam menganalisa permasalahan yang ada dan untuk melanjuktkan ke tahap penelitian berikutnya.

\section{c. Dokumentasi}

Metode dokumentasi dalam penelitian merupakan pelengkap dari penggunaan metode observasi dan wawancara. Studi dokumentasi yaitu mengumpulkan dokumen dan data-data yang diperlukan di tempat penelitian sehingga dapat mendukung dan menambah kepercayaan dan pembuktian suatu kejadian.

\section{d. Perancangan Secara Cepat}

Pada saat membangun aplikasi, Perancangan secara cepat merupakan tahapan dimana peneliti menetapkan bagaimana perangkat lunak tersebut dapat dioperasikan. Hal ini berkaitan dalam menentukan spesifikasi perangkat keras, spesifikasi perangkat lunak tampilan aplikasi dan form-form yang akan digunakan.

\subsection{Metode Pengembangan Perangkat Lunak}

Metode pengembangan perangkat lunak diperlukan untuk memudahkan peneliti dalam merancang dan menerapkan metode burte force [2] untuk smart trolly [3]pada fitrinop Swalayan. Metode yang digunakan adalah model prototype [4] yang dapat dilhat pada gambar 1 berikut ini. 


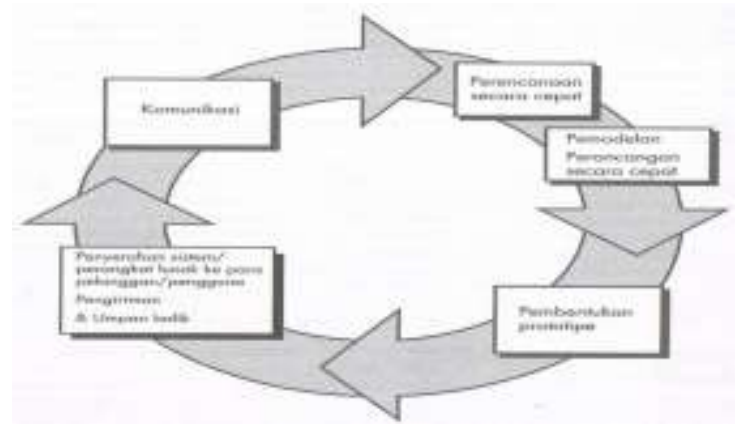

Gambar 1. Metode Prototype

\subsection{Algoritma Brute Force}

Algoritma brute force adalah algoritma yang digunakan untuk mencocokan pattern dengan semua string antara 0 dan n-m untuk menemukan keberadaan string target. Secara rinci langkah-langkah algoritma brute force untuk mencocokkan string adalah:

1. Pencocokan pattern dimulai mulai dari awal teks.

2. Algoritma brute force akan mencocokan karakter per karakter pattern dengan karakter pada teks yang bersesuaian yang dimulai dari kiri ke kanan, sampai salah satu kondisi berikut terpenuhi:

a. Karakter di pattern yang dibandingkan cocok, maka pencarian selesai.

b. Apabila dijumpai ketidak cocokan antara pattern dengan teks, maka pencarian tidak cocok dan belum berhasil.
3. Kemudian algoritma brute force terus menggeser pattern sebesar satu ke kanan, dan mengulangi langkah ke-2 sampai pattern berada di ujung teks. Pada gambar 2 berikut adalah alur flowchart dari algoritma Brute Force:

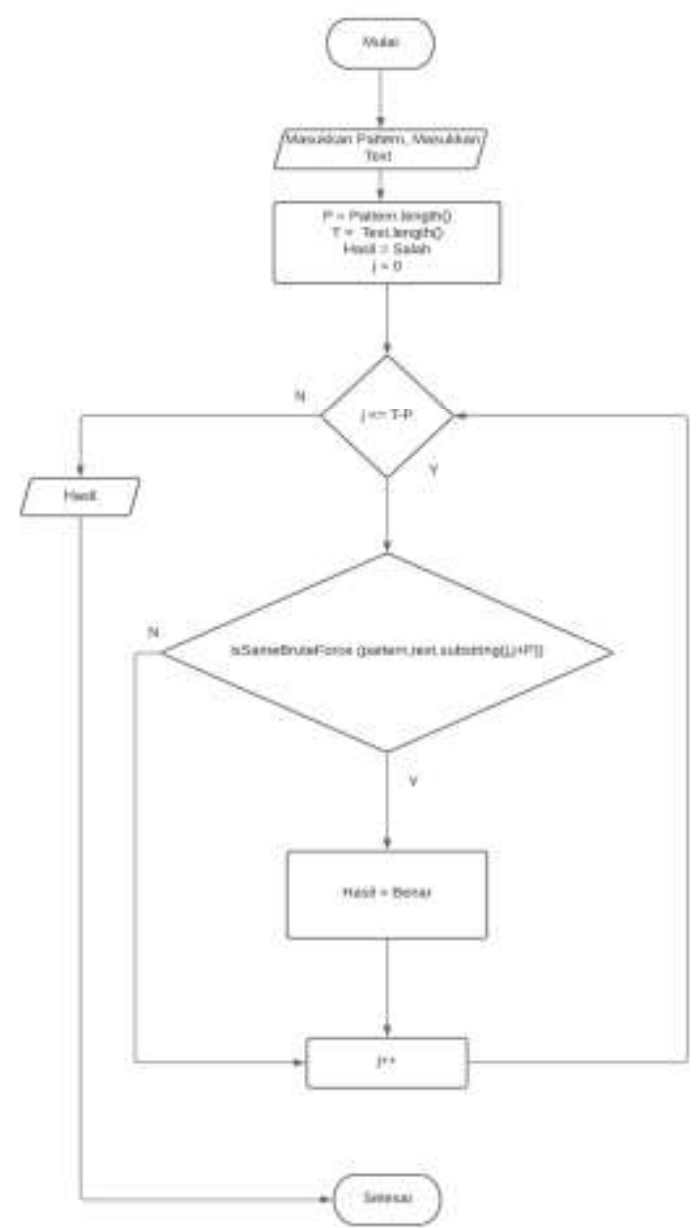

\section{Gambar 2. berikut adalah alur flowchart dari algoritma Brute Force}

Proses pencocokan pattern Nama Barang dengan kata kunci yang diinput oleh pengunjung swalayan dilakukan pada setiap record field Nama Barang. Bila diasumsikan 
kata kunci yang diinput oleh pengunjung swalayan adalah "INDOMILK", maka proses penelusuran field Nama Barang berdasarkan algoritma brute force terlihat pada tabel 1 berikut ini:

Tabel 1. Tabel Tahap-1 Pencocokan string

\begin{tabular}{|l|c|c|c|c|c|c|c|c|c|c|c|c|c|c|c|c||}
\hline \multicolumn{11}{|c||}{ Tahap ke-1 } \\
\hline $\begin{array}{l}\text { Nama } \\
\text { Barang }\end{array}$ & I & N & D & O & M & I & E &, & I & N & D & O & M & I & L & K \\
\hline $\begin{array}{l}\text { String } \\
\text { Input }\end{array}$ & I & N & D & O & M & I & L & K & & & & & & & & \\
\hline
\end{tabular}

Pencocokan huruf pertama String Input dengan huruf pertama Nama Barang, bila sama maka string ke-2 dari String input akan dibandingkan dengan String ke-2 Nama Barang, bila sama maka string ke-3 dari String Input akan dibandingkan lagi dengan String ke-3 Nama Barang begitupun seterusnya sampai ditemukan ketidak cocokan string maka pencocokan akan bergeser ke kanan, terlihat pada tabel 2 berikut ini:

Tabel 2. Tabel Tahap-2 Pencocokan string

Tahap ke-2

\begin{tabular}{|l|l|l|l|l|l|l|l|l|l|l|l|l|l|l|l|}
\hline I & N & D & O & M & I & E &, & I & N & D & O & M & I & L & K \\
\hline I & N & D & O & M & I & & & & & & & & & & \\
\hline
\end{tabular}

Karena string ke-7 pada String Input tidak sama dengan string ke-7 Nama Barang, maka posisi string input digeser ke kanan sebanyak satu kali, kemudian dilakukan proses pencocokan hingga akhir dari string Nama Barang, dapat dilihat pada table 3 berikut ini;

Tabel 3. Tabel Tahap-3 Pencocokan string

\begin{tabular}{|l|l|l|l|l|l|l|l|l|l|l|l|l|l|l|l|}
\hline I & N & D & O & M & I & E &, & I & N & D & O & M & I & L & K \\
\hline I & N & D & O & M & I & & & & & & & & & L & K \\
\hline
\end{tabular}

Proses pencocokan ditemukan bahwa String Input sama dengan string sinopsis buku, maka informasi Barang dengan Nama Barang tersebut akan disarankan kepada pengunjung swalayan dan proses pencocokan pada record tersebut berhenti. Terlihat pada table 4 berikut:

\section{Tabel 4. Tabel Tahap-4 Pencocokan} string

\begin{tabular}{|l|l|l|l|l|l|l|l|l|l|l|l|l|l|l|l|}
\hline \multicolumn{11}{|c|}{ Tahap ke-4 } \\
\hline I & $\mathbf{N}$ & $\mathbf{D}$ & $\mathbf{O}$ & $\mathbf{M}$ & $\mathrm{I}$ & $\mathrm{E}$ &, & $\mathbf{I}$ & $\mathbf{N}$ & $\mathbf{D}$ & $\mathbf{O}$ & $\mathbf{M}$ & $\mathbf{I}$ & $\mathbf{L}$ & $\mathbf{K}$ \\
\hline & & & & & & & & $\mathbf{N}$ & $\mathbf{N}$ & $\mathbf{D}$ & $\mathbf{O}$ & $\mathbf{M}$ & $\mathbf{I}$ & $\mathbf{L}$ & $\mathbf{K}$ \\
\hline
\end{tabular}

Hasil pencocokan String Input dengan seluruh String Nama Barang maka ditemukan kesamaan kata kunci "INDOMILK" pada bagian akhir. 


\section{HaSil dan Pembahasan}

\subsection{Pemodelan Perancangan Secara}

\section{Cepat}

Pada tahap desain perancangan "Smart Trolley Pada Fitrinofane Swalayan Menggunakan Metode Brute Force Berbasis Mobile[5]" ini dimulai dari desain perancangan UML (Unified Modeling Language) yaitu untuk menentukan desain Use Case Diagram, Activity Diagram dan Class Diagram [6] sebagai berikut :

\section{Use Case Diagram}

Berikut adalah Use Case Diagram dari Smart Trolley Pada Fitrinofane Swalayan Menggunakan Metode Brute Force Berbasis Mobile :

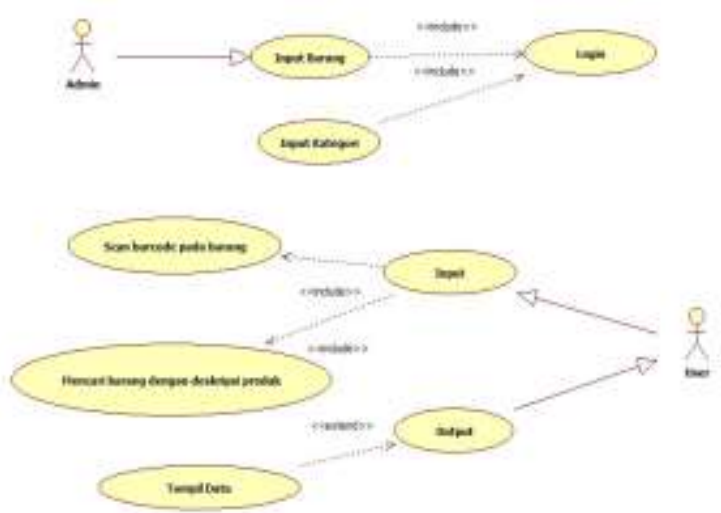

\section{Gambar 2. Use Case Diagram dari Perangkat Lunak yang Diajukan}

Gambar Use Case Diagram di atas menjelaskan bahwa Admin bertindak sebagai orang yang dapat mengelola semua data barang serta melakukan penginputan Barang dan Kategori.

\subsection{Activity Diagram}

Activity diagram berfungsi untuk memberikan visualisasi alur tindakan dalam sistem, percabangan yang mungkin terjadi, dan alur sistem yang dimulai dari awal hingga akhir. Yang akan menampilkan beberapa menu pilihan dimana dalam pilihan menu terdapat penjelasan yang akan di bahas pada masing - masing menu tersebut. Berikut adalah Activity Diagram dari Smart Trolley Pada Fitrinofane Swalayan Menggunakan Metode Brute Force Berbasis Mobile:

\section{a. Activity Diagram Admin}

Activity Diagram [7] dibawah ini berupa penggambaran alur aktivitas Admin yang memiliki akses penuh di dalam Aplikasi, dan Admin dapat menginput data barang, menginput kategori serta mengubah atau menghapus data. 


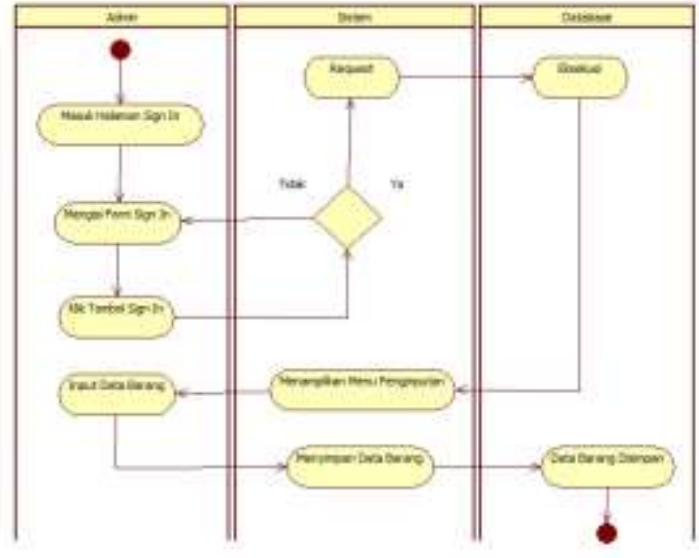

Gambar 3. Activity Diagram Admin dari Perangkat Lunak yang Diajukan

\section{b. Activity Diagram User}

Activity Diagram dibawah ini berupa penggambaran alur aktivitas yang dapat dilakukan oleh User pada Aplikasi, seperti melakukan scan barcode pada barang dan melakukan pencarian data barang menggunakan dengan menggunakan deskripsi produk.

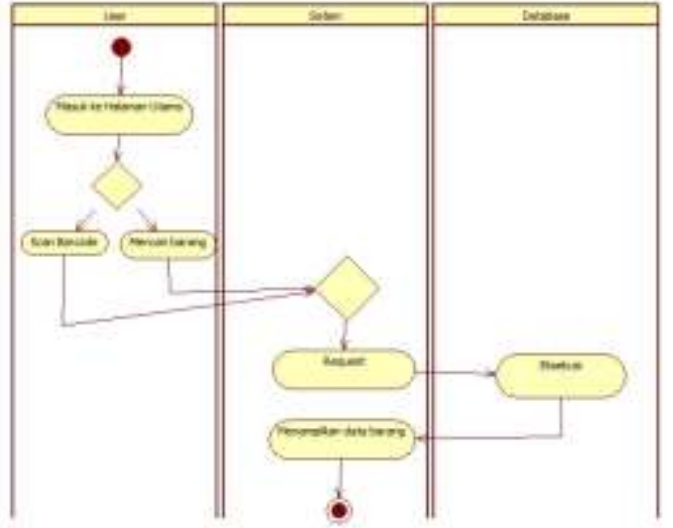

Gambar 3. Activity Diagram User dari Perangkat Lunak yang Diajukan
Class diagram menggambarkan struktur dan deskripsi class, package dan objek beserta hubungan antara satu sama lain. Berikut adalah Class Diagram dari Smart Trolley Pada Fitrinofane Swalayan Menggunakan Metode Brute Force Berbasis Mobile :

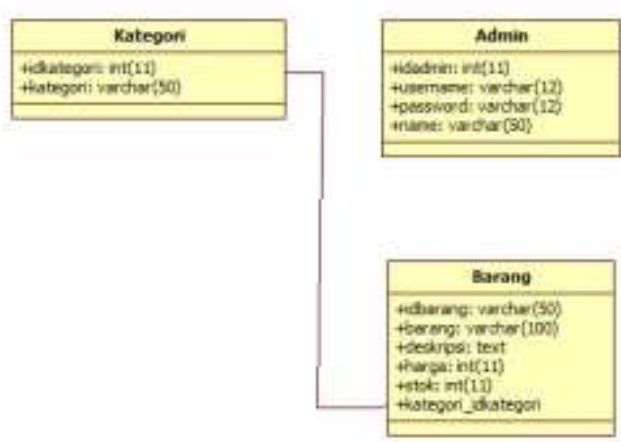

Gambar 4. Class Diagram dari Perangkat Lunak yang Diajukan

\subsection{Rancangan Interface Aplikasi}

Rancangan interface adalah desain awal sebelum membangun suatu perangkat lunak, hasil dari perangkat lunak yang dibangun nantinya tidak akan jauh berbeda dengan perancangan interface yang dibuat.

\section{a. Rancangan Interface Admin Halaman Splash Screen}

Halaman splash screen akan muncul saat pertama kali Aplikasi dijalankan, terlihat pada gambar 5 .

\subsection{Class Diagram}




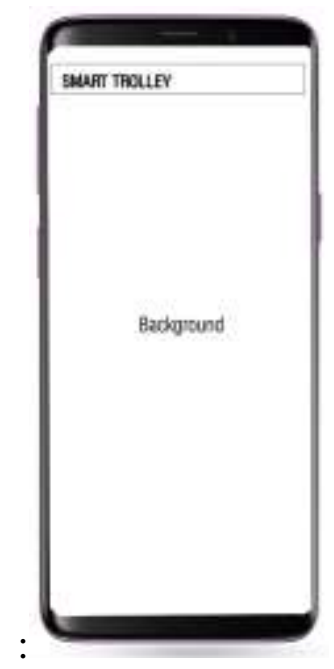

Gambar 5. Rancangan Tampilan Halaman Splash Screen

\section{b. Rancangan Interface halaman Sign In Admin}

Halaman Sign In muncul pada saat admin mengakses aplikasi dan akan muncul form sign in yaitu username dan password serta Sign In untuk masuk ke aplikasi, terlihat pada gambar 6.

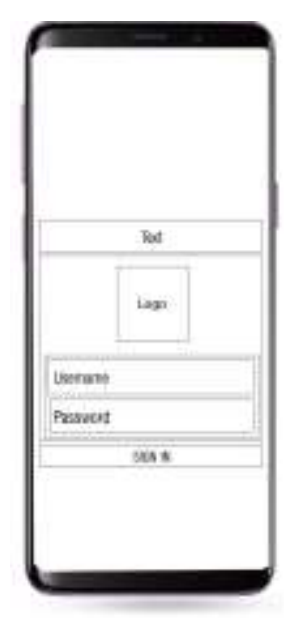

Gambar 6. Halaman Sign In Admin

\section{c. Rancangan Interface admin Halaman Tambah Barang}

Halaman Tambah Barang berguna bagi Admin untuk menambah data barang yang meliputi Kategori, ID barang, Nama Barang, Gambar Barang, Deskripsi Produk, Harga dan Stok yang tersedia, dapat terlihat pada gambar 7.

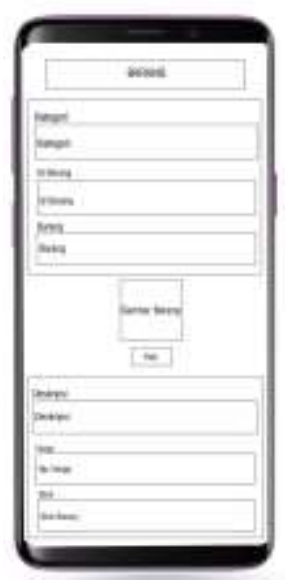

\section{Gambar 7. Tampilan Halaman Tambah Barang}

\section{d. Rancangan Interface Halaman Utama User \\ Halaman Utama User muncul pada saat user pertama kali mengakses aplikasi, pada halaman ini terdapat fitur kamera untuk melakukan scan barcode serta fitur cari barang, terlihat pada gambar 8 .}




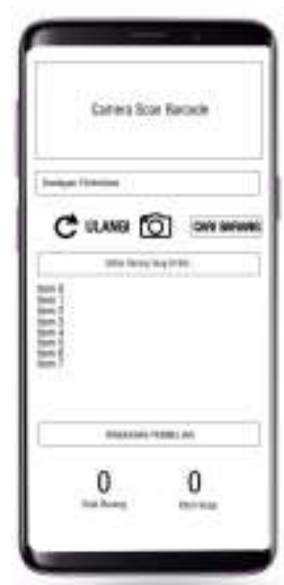

\section{Gambar 8. Rancangan Tampilan} Halaman Utama User

\section{e. Rancangan Interface Halaman Hasil Pencarian Barang}

Halaman ini menampilkan hasil pencarian barang dengan deskripsi produk dan hasil scan barcode [8], terlihat pada gambar 9 .

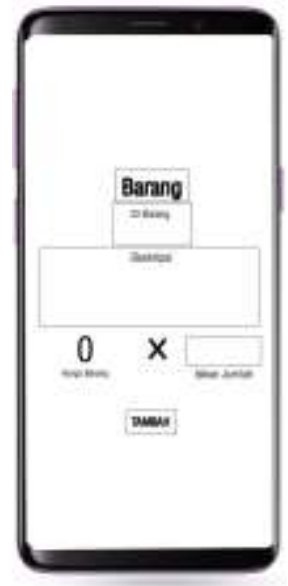

Gambar 8. Halaman Hasil Pencarian Barang

\section{5 . Hasil Interface Aplikasi}

Berikut tampilan interface dari "Smart Trolley Pada Fitrinofane Swalayan
Menggunakan Metode Brute Force Berbasis Mobile" yang di bangun :

\section{a. Tampilan Interface Halaman Splash Screen}

Halaman splash screen akan muncul saat pertama kali aplikasi dijalankan, terlihat pada gambar 9 .

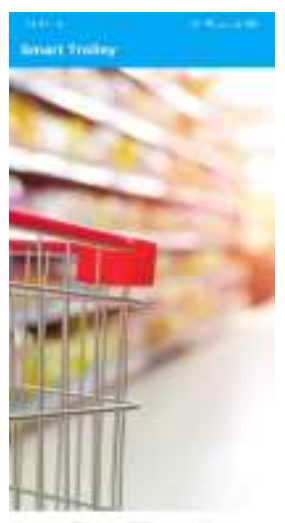

Gambar 9. Interface Halaman Splash Screen

\section{b. Tampilan Interface Halaman Sign In Admin}

Halaman Sign In muncul pada saat admin mengakses aplikasi dan akan muncul form sign in yaitu username dan password serta Sign In untuk masuk ke aplikasi, terlihat pada gambar 10. 

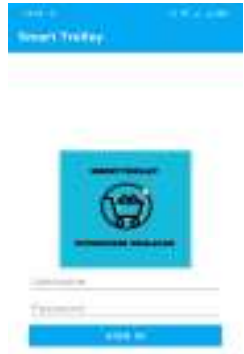

Gambar 10. Interface Halaman Sign In Admin

\section{c. Tampilan Interface Menu Tambah Barang}

Halaman Tambah Barang berguna bagi Admin untuk menambah data barang yang meliputi Kategori, ID barang, Nama Barang, Gambar Barang, Deskripsi Produk, Harga dan Stok yang tersedia, terlihat pada gambar 11 .

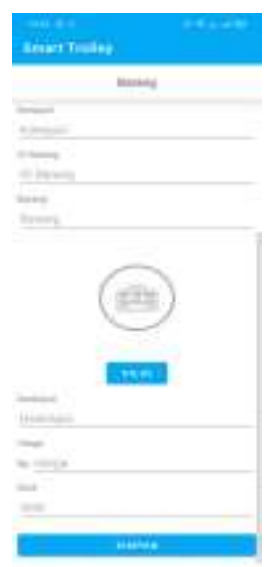

Gambar 11. Interface Halaman tambah barang

\section{d. Interface Halaman Hasil Input Barang}

Halaman Hasil Input Barang berisi hasil inputan barang yang telah diinput oleh Admin, terlihat pada gambar 12 .

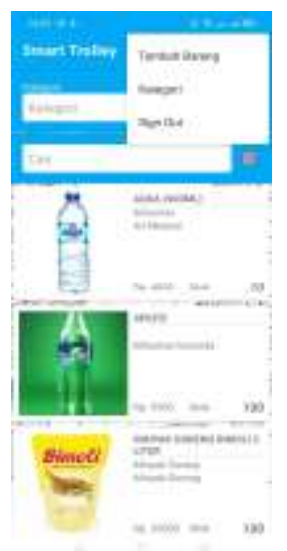

\section{Gambar 12. Interface Hasil Input Barang}

\section{e. Interface Hasil Scan Barcode dan Cari Barang}

Halaman ini menampilkan hasil scan barcode dan pencarian barang dengan deskripsi produk oleh pengguna, terlihat pada gambar 13 berikut:

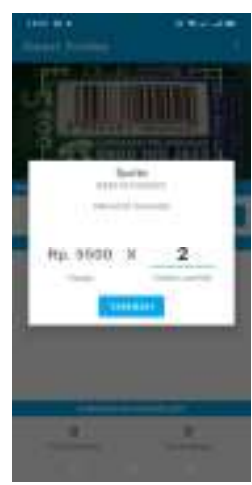

Gambar 13. Interface hasil scan barcode dan pencarian barang 


\subsection{Pembahasan}

Aplikasi ini digunakan untuk untuk mengontrol anggaran belanja konsumen dan memudahkan dalam proses pembayaran karena tidak perlu lagi menunggu petugas kasir untuk mengakumulasi harga barang yang dibeli satu persatu. Setelah tahap pembuatan aplikasi selesai tahap selanjutnya yaitu tahap build aplikasi menjadi aplikasi berformat .apk untuk selanjutnya di install di perangkat android.

\subsection{Hasil Pengujian Aplikasi}

Hasil pengujian (testing) aplikasi yang telah dibuat menggunakan Black box testing. Pengujian ini dimaksudkan untuk mengevalusi hasil. Hasil pengujian dapat terlihat dalam sub bab berikut:

\section{a. Hasil Pengujian Fungsi Kinerja Loading}

Pengujian ini dilakukan saat aplikasi mulai dijalankan sampai menampilkan halaman pada android yang dipakai dalam pengujian. Berikut hasil perbedaan waktu loading pada tabel 1 .

\section{Tabel 5. Hasil Pengujian Fungsi Kinerja Loading}

\begin{tabular}{|l|l|l|l|}
\hline \multirow{2}{*}{ Proses } & \multicolumn{3}{|c|}{ Waktu Loading(Detik) } \\
\cline { 2 - 4 } & Device 1 & Device 2 & Device 3 \\
\hline
\end{tabular}

\begin{tabular}{|l|c|c|c|}
\hline $\begin{array}{l}\text { Loading } \\
\text { membuka } \\
\text { aplikasi }\end{array}$ & 0,5 & 0,4 & 0,2 \\
\hline
\end{tabular}

\section{b. Pembahasan Hasil Pengujian Interface}

Hasil pengujian interface yang telah dilakukan, dapat dilihat pada tabel 6 .

Tabel 6. Hasil Pengujian Interface

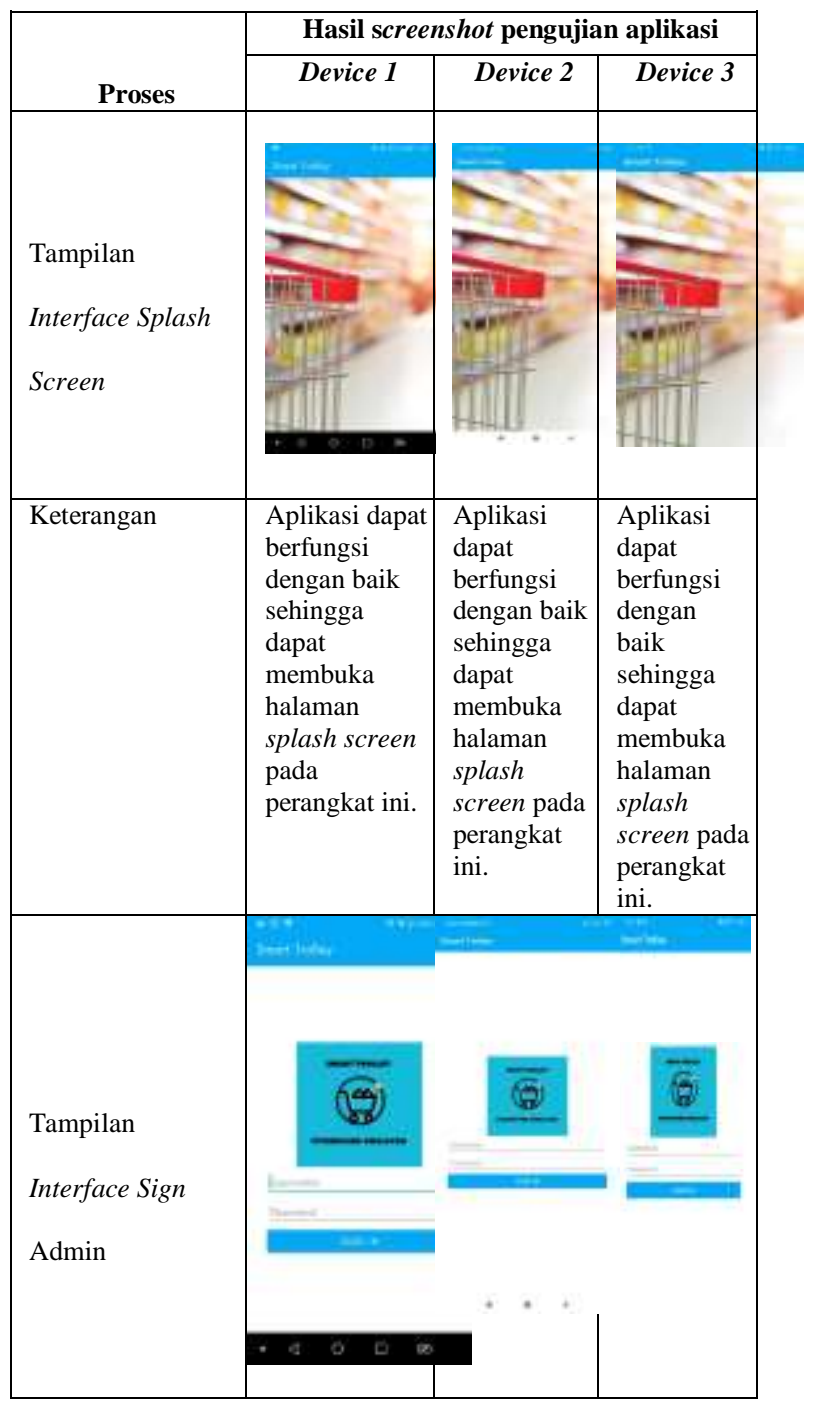




\begin{tabular}{|c|c|c|c|}
\hline Keterangan & $\begin{array}{l}\text { Aplikasi } \\
\text { dapat } \\
\text { berfungsi } \\
\text { dengan baik } \\
\text { sehingga } \\
\text { dapat } \\
\text { membuka } \\
\text { halaman } \\
\text { sign admin } \\
\text { pada } \\
\text { perangkat } \\
\text { ini. }\end{array}$ & $\begin{array}{l}\text { Aplikasi } \\
\text { dapat } \\
\text { berfungsi } \\
\text { dengan baik } \\
\text { sehingga } \\
\text { dapat } \\
\text { membuka } \\
\text { halaman } \\
\text { sign admin } \\
\text { pada } \\
\text { perangkat } \\
\text { ini. }\end{array}$ & $\begin{array}{l}\text { Aplikasi } \\
\text { dapat } \\
\text { berfungsi } \\
\text { dengan } \\
\text { baik } \\
\text { sehingga } \\
\text { dapat } \\
\text { membuka } \\
\text { halaman } \\
\text { sign admin } \\
\text { pada } \\
\text { perangkat } \\
\text { ini }\end{array}$ \\
\hline
\end{tabular}

\section{SIMPULAN}

Pada penelitian Smart Trolley Pada Fitrinofane Swalayan Menggunakan Metode Brute Force Berbasis Mobile [9] ini dapat diambil kesimpulan sebagai berikut:

1. Aplikasi yang dibangun dapat digunakan oleh konsumen untuk memudahkan konsumen dalam mengetahui akumulasi harga barang belanjaan secara langsung dengan menggunakan scan barcode [10] pada barang.

2. Aplikasi ini mampu berjalan pada sistem operasi android dengan minimal versi 8.0 Oreo.

3. Aplikasi ini dapat memudahkan konsumen dalam mencari barang yang diinginkan dengan menggunakan fitur pencarian berdasarkan deskripsi produk dan kategori produk.

4. Konsumen dapat mengontrol anggaran belanja sesuai dengan budget yang dimiliki tanpa perlu khawatir pada saat transaksi dikasir.
5. Memudahkan proses transaksi pembayaran serta meminimalisir antrean yang lama di kasir.

6. Berdasakan hasil uji Black Box testing, dari beberapa uji komponen yang dilakukan diantaranya: Device 1 dengan android versi 8.0, Device 2 dengan android versi 9.0 dan Device 3 dengan android versi 10. Semua komponen uji berhasil dilakukan, yang membedakan adalah tampilan aplikasi dari masingmasing device karena perbedaan ukuran layar.

\section{PENELITIAN LANJUTAN}

Saran pada penelitian Smart Trolley Pada Fitrinofane Swalayan Menggunakan Metode Brute Force Berbasis Mobile yang telah dibangun ini adalah sebagai berikut:

1. Diharapkan pada penelitian selanjutnya terdapat perangkat yang mendukung seperti resolusi kamera yang baik untuk melakukan scan barcode.

2. Aplikasi ini diharapkan dapat dikembangkan di tipe perangkat $i O S$ dan lainnya.

3. Aplikasi ini diharapkan dapat dikembangkan untuk digunakan di swalayan atau pertokoan lain.

4. Aplikasi ini diharapkan dapat dikembangkan dengan metode lain 
sampai terhubung dengan kasir sehingga

kasir dapat langsung menerima informasi

total pembelian barang dan memvalidasi secara langsung.

\section{DAFTAR PUSTAKA}

[1] R. Saputra, Pitoyo Yuliatmojo, and Aodah Diamah, "PROTOTYPE KERANJANG BELANJA PINTAR BERBASIS ARDUINO UNO," $J$. Pendidik. VOKASIONAL Tek.

Elektron., vol. 2, no. 2, 2019, doi: 10.21009/jvote.v2i2.13573.

[2] B. W. Santoso, F. Sundawa, and M. Azhari, "Implementasi Algoritma Brute Force Sebagai Mesin Pencari ( Search Engine ) Berbasis Web Pada Database," J. Sisfotek Glob., vol. 6, no. $1,2016$.

[3] H. Widya, S. Syafrawali, and R. Salsabila, “Aplikasi Barcode Scanner Food Halal Pada Produk Makanan Impor Berbasis Android," J. Electr. Technol., vol. 4, no. 1, 2019.

[4] R. Pressman, "Rekayasa Perangkat Lunak: Pendekatan Praktisi Buku I,"

J. Inf. Politek. Indonusa Surakarta ISSN, vol. 4, no. 1, 2015.

[5] Y. P. Sari, "Game Edukasi Kesenian Lampung Berbasis Android," in
Seminar Nasional Hasil Penelitian dan Pengabdian IBI DARMAJAYA, 2019, vol. 1.

[6] H. Gunawan and Y. P. Sari, "Sosialisasi Pembuatan E-KTP Berbasis Android," 2017.

[7] Haviluddin, A. T. Haryono, and D. Rahmawati, "Aplikasi program php dan Mysql," Mulawarman Univ. Press, vol. 53, no. 9, 2016.

[8] I. C. Ishak, M. M. Muslim, S. B. Ismail, M. A. Mun'aim Mohd Idrus, and M. M. Ali, "A smart trolley with rfid implementation: A survey among customers," ARPN J. Eng. Appl. Sci., vol. 12, no. 4, 2017.

[9] Ni Ketut Dewi Ari Jayanti, "Penggunaan Algoritma Floyd Warshall Dalam Masalah Jalur Terpendek Pada Penentuan Tata Letak Parkir," Semin. Nas. Inform., vol. 1, 2014.

[10] J. L. Anderson, M. L. MacUrak, M. E. Halpern, and S. A. Farber, "A versatile aquatics facility inventory system with real-time barcode scan entry," Zebrafish, vol. 7, no. 3, 2010, doi: 10.1089/zeb.2010.0661. 